\section{Suspected anaphylactic reaction to Cremophor EL}

There have been several reports of anaphylactoid reactions to the intravenous anaesthetic drugs Althesin (alphaxalone and alphadolone) and propanidid (Epontol). ${ }^{1}$ The culprit in some of these reactions may have been Cremophor EL, a surfactant common to both drug formulations. Cremophor EL is produced by the epoxylation of castor oil and is actually a complex mixture of compounds. We report a case in which the clinical and laboratory evidence indicated that Cremophor EL was the cause of an anaphylactic (antibodymediated) response.

\section{Case report}

An otherwise fit 14-year-old girl had an ankle fracture reducud on 15 June 1979. The anaesthetic consisted of atropine $0.6 \mathrm{mg}$, Althesin $4 \mathrm{ml}$ nitrous oxide, oxygen, halothane, and trichloroethylene. The patient had never previously had a general anaesthetic. The operation was not entirely successful, and the patient presented again on 27 June for internal fixation. Anaesthesia was induced with propanidid injected into an antecubital vein. After the injection of about $20 \mathrm{mg}$ the solution began to extravasate, and the injection was stopped. The anaesthetic was continued with nitrous oxide, oxygen, and halothane. The patient coughed and became cyanosed and then unconscious. Anaesthesia was discontinued. Peripheral vascular shutdown with absent radial pulses was noted; large arterial pulses were present. There was a pronounced expiratory wheeze. About 1.51 colloid (Haemaccel) and crystalloid (Hartmann's solution) was infused intravenously with dexamethasone and aminophylline. The patient's colour began to improve after about 20 minutes and she recovered consciousness. A salbutamol infusion was begun because she still had an expiratory wheeze. Some two hours after induction she was fully conscious with normal blood gas tensions while breathing room air. Blood was taken for complement and other plasma protein studies and also for haematological tests since she was bleeding extensively from venepuncture sites, suggesting an impaired haemostatic mechanism. Four days later she was given without incident an anaesthetic with no intravenous induction agents.

Concentrations of fibrin degradation products were raised at both two hours $(0.16 \mathrm{~g} / \mathrm{l})$ and 24 hours $(0.04 \mathrm{~g} / \mathrm{l})$. Other haematological values were normal. Plasma complement C3 concentration $(0.6 \mathrm{~g} / \mathrm{l})$ was normal, C4 concentration $(0.07 \mathrm{~g} / \mathrm{l})$ was very low, and $\mathrm{IgE}$ concentration $(335 \mathrm{IU} / \mathrm{ml})$ rather high and characteristic of allergy. The plasma samples showed massive $(\geqslant 80 \%$ ) initial C3 conversion (fig), the effects of which would be consistent with the clinical manifestations.

\section{Comment}

The patient had no history of allergy or atopy, although her father had had an allergic-type reaction to an injection of phenobarbitone many years previously. Nevertheless, she had a low plasma C4

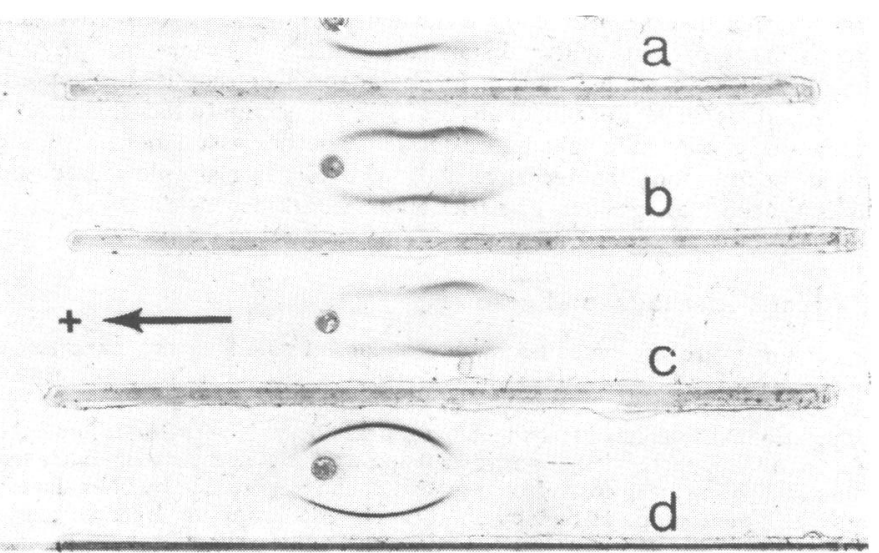

Agar immunoelectrophoresis of sequential EDTA plasma samples from patient after adverse reaction. Sample $(d)$ is a totally converted serum sample used as control. Electrophoresis is towards left of plate: "slits" contain commercial anti-C 3 serum. Patient samples taken $(a) 2$ hours, $(b) 5$ hours, (c) 20 hours after reaction. Initial high concentration of conversion products in (a) (compare control $(d)$ ) falls gradually since they are biodegraded and replaced with fresh native $\mathrm{C} 3$ in $(c)$. concentration and an IgE concentration consistent with immunological hypersensitivity, and the interval between exposures to Cremophor EL was short. These three factors are said to predispose to an anaphylactoid response. ${ }^{1}$ Evidence is steadily accumulating of the antigenicity of Cremophor EL, which is common to both Althesin and propanidid formulations. Although memory-mediated events after a second exposure to Althesin have been reported in man, ${ }^{2}$ Glen $e t a l^{3}$ have shown that Cremophor EL alone can cause anaphylactic reactions when readministered to the miniature pig within one to three weeks. They also noted that although an active component of Althesin (alphaxalone) produced the same memorymediated effect when given to the pig in a different solvent propanidid itself was inert. In addition to anaesthetic reactions clinically severe adverse reactions, with plasma C3 conversion, have been reported ${ }^{4}$ in man after intravenous diazepam solubilised in Cremophor EL.

The circumstantial evidence in our patient points to an immunological memory-mediated event directed against Cremophor EL. A direct C3 activation from propanidid but not alphaxalone seems unlikely since the pig experiments indicate that Cremophor and not propanidid is likely to be involved in anaphylactic reactions. More probably Cremophor triggered an immune-mediated reaction in our patient, rapidly reducing the low $\mathrm{C} 4$ concentration, and then activated the alternative pathway. If the reaction was not immune-mediated then the Cremophor in Althesin should also have elicited an adverse reaction on the first occasion. A further point of interest was the raised production of fibrinogen degradation products. Although this may have been a non-specific result of vascular collapse, it may have arisen from complement activation. ${ }^{5}$

We thank Mr K A Ennis and Dr C D Day for permission to investigate and report this case.

1 Watkins J. Anaphylactoid reactions to iv substances. Br $\mathcal{F}$ Anaesth 1979; 51:51-60.

2 Watkins J, Clark A, Appleyard TN, Padfield A. Immune mediated reactions to Althesin (alphaxalone). Br $\mathcal{F}$ Anaesth 1976;48:881-6.

3 Glen JB, Davies GE, Thomson DS, Scarth SC, Thompson AV. An animal model for the investigation of adverse responses to iv anaesthetic agents and their solvents. BrF Anaesth 1979;51:819-27.

${ }^{4}$ Hüttel MS, Schou Olesen A, Stoffersen E. Complement mediated reactions to diazepam with Cremophor as solvent (Stesolid MR). Br $\mathcal{F}$ Anaesth 1980;52:77-9.

${ }^{5}$ Preston FE. Haematological problems associated with shock. or $\mathfrak{f}$ Hosp Med $1979 ; 21: 232-45$.

(Accepted 1 February 1980)

Departments of Anaesthetics and Immunology, Hallamshire Hospital Medical School, Sheffield S10 2RX

D DYE, BSC, FFARCS, senior registrar in anaesthetics

$\mathrm{J}$ WATKINS, PHD, deputy director, protein reference unit

\section{Diabetic glucose control, lipids, and trace elements on long-term guar}

Recent criticism of the effectiveness of high-fibre diets in the treatment of diabetics has, in part, been due to failure to mix the fibre adequately with the carbohydrate portion of the diet. There is, however, also genuine fear that the benefits may wear off with time ${ }^{1}$ or that long-term administration of fibre may cause mineral depletion. ${ }^{2}$ We therefore present data on the longer-term effects of dietary supplementation with guar.

\section{Patients, methods, and results}

Eleven diabetic patients $(6$ men, 5 women aged $48 \pm$ SD 5 years and weighing $110 \pm 7 \%$ of ideal weight) were studied; eight were being treated with insulin (49 U/day), two (cases 2 and 11) with oral agents, and one (case 13) with diet alone. All completed six months of eating 14-26 g guar/day in crispbread form, and eight were followed up into their second year. Of the remaining three, one (case 11) was placed on insulin, while distance from the centre made follow-up of the remaining two (cases 4 and 7) difficult. Urinary 
Mean urinary glucose concentrations and insulin dose before and during one year of guar administration

\begin{tabular}{|c|c|c|c|c|c|c|c|c|}
\hline \multirow{2}{*}{ Case No } & \multirow{2}{*}{$\begin{array}{c}\text { Before } \\
\text { guar }\end{array}$} & \multicolumn{7}{|c|}{ Week } \\
\hline & & 4 & 8 & 12 & 16 & 20 & 24 & 52 \\
\hline $\begin{array}{r}2 \\
3 \\
4 \\
5 \\
6 \\
7 \\
8 \\
10 \\
11 \\
12 \\
13\end{array}$ & $\begin{array}{r}83.2 \\
16.6 \\
27.7 \\
27.7 \\
83.3^{*} \\
111.0 \\
55.6 \\
30.0 \\
111.1 \\
16.7 \\
19.7\end{array}$ & $\begin{array}{r}7 \cdot 2 \\
3.9 \\
26.1 \\
15.6 \\
28.9 \\
1 \overline{15 \cdot 0} \\
35.6 \\
13.9 \\
37.8 \\
1.5\end{array}$ & $\begin{array}{c}\text { Mean uri } \\
5.5 \\
2.2 \\
69.4 \\
31.1 \\
27.7 \\
22.2 \\
8.9 \\
35.6 \\
19.4 \\
23.9 \\
8.5\end{array}$ & $\begin{array}{c}\text { ary glucos } \\
11 \cdot 1 \\
3.9 \\
43.3 \\
23.9 \\
30.0 \\
10.0 \\
35.6 \\
10.0 \\
13.9 \\
13.2\end{array}$ & $\begin{array}{c}e(m m o l / l) \\
2.2 \\
4.4 \\
55.6 \\
22.2 \\
28.9 \\
17.3 \\
17.8 \\
21.7 \\
4.4 \\
5.8\end{array}$ & $\begin{array}{r}10 \cdot 6 \\
2 \cdot 8 \\
55 \cdot 6 \\
20 \cdot 0 \\
42 \cdot 8 \\
44 \cdot 4 \\
22 \cdot 2 \\
16 \cdot 1 \\
3 \cdot 3 \\
23 \cdot 9 \\
28 \cdot 8\end{array}$ & $\begin{array}{r}22.8 \\
6.7 \\
55.6 \\
49.4 \\
27.8 \\
87.8 \\
15.0 \\
23.9 \\
33.9 \\
40.6 \\
16.5\end{array}$ & $\begin{array}{r}22 \cdot 8 \\
3 \cdot 3 \\
25 \cdot 6 \\
17 \cdot 8 \\
13 \cdot 3 \\
27 \cdot 8 \\
25 \cdot 6 \\
3 \cdot 6\end{array}$ \\
\hline $\begin{array}{l}\text { Mean } \\
\pm \text { SEM } \\
\text { p }\end{array}$ & $\begin{array}{r}53.0 \\
\pm 11.3\end{array}$ & $\begin{array}{c}18.6 \\
\pm 4.1 \\
<0.05\end{array}$ & $\begin{array}{r}23.1 \\
\pm 5.7\end{array}$ & $\begin{array}{l}19.5 \\
\pm 4 \cdot 1 \\
<0.05\end{array}$ & $\begin{array}{l}18.1 \\
\pm 5.1 \\
<0.05\end{array}$ & $\begin{array}{l}24.6 \\
\pm 5.2 \\
<0.05\end{array}$ & $\begin{array}{l}34.6 \\
\pm 7.0 \\
\text { NS }\end{array}$ & $\begin{array}{l}17.5 \\
\pm 3.5 \\
<0.05\end{array}$ \\
\hline $\begin{array}{r}2 \\
3 \\
4 \\
5 \\
6 \\
7 \\
8 \\
10 \\
11 \\
12 \\
13\end{array}$ & $\begin{array}{r}0 \\
26 \\
58 \\
52 \\
36 \\
56 \\
44 \\
44 \\
0 \\
76 \\
0\end{array}$ & $\begin{array}{r}0 \\
19 \\
48 \\
39 \\
36 \\
28 \\
38 \\
0 \\
66 \\
0\end{array}$ & $\begin{array}{c}0^{I n} \\
19 \\
31 \\
34 \\
35 \\
40 \\
30 \\
38 \\
0 \\
66 \\
0\end{array}$ & $\begin{array}{c}\text { ulin }(U / 24 \\
0 \\
20 \\
34 \\
34 \\
32 \\
40 \\
28 \\
38 \\
0 \\
64 \\
0\end{array}$ & h) $\begin{array}{r} \\
0 \\
20 \\
32 \\
32 \\
28 \\
36 \\
28 \\
40 \\
0 \\
64 \\
0\end{array}$ & $\begin{array}{r}0 \\
20 \\
38 \\
32 \\
31 \\
34 \\
28 \\
40 \\
0 \\
58 \\
0\end{array}$ & $\begin{array}{r}0 \\
16 \\
36 \\
32 \\
34 \\
36 \\
28 \\
40 \\
0 \\
57 \\
0\end{array}$ & $\begin{array}{r}0 \\
17 \\
32 \\
34 \\
26 \\
\frac{40}{56} \\
0\end{array}$ \\
\hline $\begin{array}{l}\text { ean } \\
\text { SEM }\end{array}$ & $49 \pm 5$ & $\begin{array}{l}39 \pm 6 \\
<0.01\end{array}$ & $\begin{array}{l}37 \pm 5 \\
<0.01\end{array}$ & $\begin{array}{l}36 \pm 5 \\
<0.002\end{array}$ & $\begin{array}{l}31 \pm 6 \\
<0.002\end{array}$ & $\begin{array}{l}35 \pm 4 \\
<0.002\end{array}$ & $\begin{array}{l}35 \pm 4 \\
<0.002\end{array}$ & $\begin{array}{l}34 \pm 5 \\
<0.02\end{array}$ \\
\hline
\end{tabular}

*This value differs from the figure in the original report, ${ }^{3}$ which has been corrected due to availability of complete first week pretreatment urine charts.

$p=$ Significance of mean absolute differen

Conversion: SI to traditional units-Glucose: $1 \mathrm{mmol} / 1 \approx 18 \mathrm{mg} / 100 \mathrm{ml}$.

glucose and insulin values over one year are shown in the table. The case numbers are the same as those in our original publication.

Each urinary glucose value represents the mean result of seven consecutive days' home urine tests on fresh urine specimens passed immediately before breakfast, lunch, dinner, and bed and performed by the patients using Clinitest tablets (Ames). In case 4 the values represent the results of only two to three days' testing. No changes were made in the insulin regimen, apart from changes in dose, or in the diet, except in one patient (case 11) who was given an essentially vegetarian diet while in the hospital metabolic ward before he started to take guar. His daily carbohydrate intake was increased from an average of $150 \mathrm{~g}$ daily to $200 \mathrm{~g}$ largely at the expense of fat and he was subsequently encouraged to maintain this diet while taking guar.

At six months, the fasting blood glucose of the 11 diabetics had risen nonsignificantly by $0.6 \mathrm{mmol} / 1(11 \mathrm{mg} / 100 \mathrm{ml})(4 \%)$ from $14.1 \pm 1.5 \mathrm{mmol} / 1$ $(254 \pm 27 \mathrm{mg} / 100 \mathrm{ml})$ and their body weight fallen by $2.2 \mathrm{~kg}(3.4 \% ; \mathrm{p}<0.01)$. In the eight who were followed up for one year mean fasting blood glucose, which was $13.2 \pm 1.9 \mathrm{mmol} / 1(238+34 \mathrm{mg} / 100 \mathrm{ml})$ before guar, remained the same at $13.3 \pm 2 \cdot 0 \mathrm{mmol} / 1(240 \pm 36 \mathrm{mg} / 100 \mathrm{ml})$ while their weight fell by $1.9 \mathrm{~kg}(3 \% ; \mathrm{p}<0.02)$ below the pre-guar value. Two individuals (cases 11 and 2) were withdrawn from the study at 6 and 12 months respectively and placed on 48 and 24 units of insulin. Immediately before insulin, while still on guar, their weights showed falls of $2.7 \mathrm{~kg}(4.4 \%)$ and $2.3 \mathrm{~kg}(5.4 \%)$ and fasting blood glucose values were reduced by $4 \mathrm{mmol} / 1(72 \mathrm{mg} / 100 \mathrm{ml})$ $(26 \%)$ and $2 \mathrm{mmol} / 1(36 \mathrm{mg} / 100 \mathrm{ml})(24 \%)$ respectively. Three patients (cases 4, 5, and 12) who had always suffered from hypoglycaemic episodes and lived at a distance from the centre voluntarily reduced their insulin dose excessively and showed increased glycosuria and fasting blood glucose values. Urinary glucose concentrations were, however, lower in all those whose insulin was not reduced more than $19 \mathrm{U} /$ day.

Other mean values measured before and after six months of guar treatment (in only eight patients) were: total cholesterol $5.0 \pm 0.2$ and $4.5 \pm 0.3$ $\mathrm{mmol} / 1(193 \pm 8-178 \pm 12 \mathrm{mg} / 100 \mathrm{ml})(\mathrm{p}<0.05)$; high density lipoprotein cholesterol $1 \cdot 2 \pm 0.2$ and $1 \cdot 3 \pm 0.1 \mathrm{mmol} / 1(46+8-50 \pm 4 \mathrm{mg} / 100 \mathrm{ml}) ;$ low density lipoprotein cholesterol $3 \cdot 2+0 \cdot 2$ and $2 \cdot 6 \pm 0.3 \mathrm{mmol} / \mathrm{l}(123+8$ $100 \pm 12 \mathrm{mg} / 100 \mathrm{ml})(\mathrm{p}<0.01)$; triglyceride $1.2 \pm 0.2$ and $1.3 \pm 0.3 \mathrm{mmol} / 1$ $(106 \pm 18-115 \pm 27 \mathrm{mg} / 100 \mathrm{ml}) ; z^{2}$ zinc $^{\prime} 1 \cdot 20 \pm 0.06$ and $1 \cdot 15 \pm 0.05 \mathrm{mmol} / \mathrm{l}$ $(7 \cdot 8 \pm 0 \cdot 4-7.5 \pm 0.3 \mathrm{mg} / 100 \mathrm{ml}) ;$ copper $1 \cdot 14 \pm 0.13$ and $1.07 \pm 0.06 \mathrm{mmol} / \mathrm{l}$ $(7 \cdot 3+0.8-6 \cdot 8 \pm 0.4 \mathrm{mg} / 100 \mathrm{ml})$; calcium $2 \cdot 30+0.02$ and $2.36+0.03 \mathrm{mmol} / \mathrm{l}$ $(9 \cdot 4 \pm 0 \cdot 08-9 \cdot 4 \pm 0 \cdot 12 \mathrm{mg} / 100 \mathrm{ml}) ;$ urea $7 \cdot 0 \pm 0.4$ and $7 \cdot 6 \pm 0.4 \mathrm{mmol} / 1$ $(42 \pm 2 \cdot 4-46 \pm 2 \cdot 4 \mathrm{mg} / 100 \mathrm{ml})$; and creatinine $83 \pm 5$ and $84 \pm 5 \mathrm{mmol} / \mathrm{l}$ $(0.9 \pm 0.06-1 \cdot 0 \pm 0.06)$

\section{Comment}

We conclude, therefore, that providing the insulin dose is not reduced by more than about a quarter, long-term guar treatment is associated with reduced urinary glucose concentrations, as in short-term studies. $^{3}$ In addition, at six months there was a $15 \%$ reduction in the low density lipoprotein fraction of the total cholesterol without a reduction in the high density lipoprotein cholesterol. A reduction in this fraction is thought to protect against cardiovascular disease.4 We find no evidence from blood values that guar causes trace-element deficiency.

We thank Dr T D Kellock, Dr B F Brearly, Dr D E Child, Dr W P Stephens, Dr S A Kumar, Dr M Nuvolini, and Dr P Griffiths for help in the follow-up of their patients. We are greatly indebted to the patients. Mr David Heath and Mr Peter Lees of Speywood Laboratories, Bingham, Nottingham made these studies possible by developing and supplying guar crispbread.

The work was supported by grants to DJAJ by the British Diabetic Association and the Medical Research Council.

${ }^{1}$ Cohen M, Martin FIR. Guar crispbread in the diabetic diet. $\mathrm{Br}$ Med $\mathcal{f}$ $1979 ; \mathrm{i}: 616$.

${ }^{2}$ Reinhold JG, Faradji B, Abadi P, Ismail-Beigi F. Decreased absorption of calcium, magnesium, zinc, and phosphorus by humans due to increased fibre and phosphorus consumption as wheat bread. $\mathcal{f}$ Nutr $1976 ; 106: 493-503$.

${ }^{3}$ Jenkins DJA, Wolever TMS, Nineham R, et al. Guar crispbread in the diabetic diet. $B r$ Med $\mathcal{F} 1978$;ii:1744-6.

4 Gordon T, Castelli WP, Hjiortland MC, Kannel WB, Dawber TR. High density lipoprotein as a protective factor against coronary heart disease. Am $\mathcal{F}$ Med 1977;62:707-14.

(Accepted 19 February 1980)

Department of the Regius Professor of Medicine, Radclifie Infirmary, Oxford

DAVID J A JENKINS, DM, research associate

University Laboratory of Physiology, Oxford

THOMAS M S WOLEVER, MSC, research fellow

Department of Gastroenterology, Central Middlesex Hospital, London NW10

RODNEY H TAYLOR, MRCP, research senior registrar

Department of Chemical Pathology, Royal Postgraduate Medical School, London W12

DAVID REYNOLDS, MRCPATH, senior registrar

University Laboratory of Physiology, Oxford

RICHARD NINEHAM, BA, research scholar (Mr Nineham died on 25 August 1979)

Radcliffe Infirmary, Oxford

T DEREK R HOCKADAY, DPHIL, FRCP, consultant physician

\section{The occupational therapist and the patient with Parkinson's disease}

Levodopa has transformed the management of patients with Parkinson's disease, but drug treatment is not wholly effective and leaves many patients with substantial disability. The place of physiotherapy in improving function in Parkinson's disease is undisputed, but there is little guidance on the role of occupational therapy..$^{1-3}$ This study was undertaken to establish whether assessment at home by an occupational therapist and the provision of simple aids could assist in the management of patients with Parkinson's disease.

\section{Patients, methods, and results}

Patients were contacted through the local branch of the Parkinson's Disease Society and through neurologists at the Glasgow Institute of Neurological Sciences and asked whether they wanted a visit from an occupational therapist. After the general practitioner's permission had been obtained, they were visited and a detailed account of their daily activities compiled. Their need for aids was assessed, and any needed but not already provided were supplied free by the branch. Aids supplied were costed at 1979 prices. Patients were visited again six to 18 months later, their condition reassessed, the usefulness of the aids inquired into, and any additional aids needed supplied.

Eighty-one patients ( 40 women and $41 \mathrm{men}$ ) were seen; 68 were over 60 years of age; 66 were under the care of consultants; and 29 had been seen by an occupational therapist at some time in the past. Twenty-three were considered not disabled, 20 disabled (incapable of living at home without help, but not needing help for self-care), and 37 dependent (needing help 